\title{
MEDICUS EUROPAEUS: PROF. PAVEL SCHMIDT, MD, PHD (*25 NOVEMBER 1933 - †11 MARCH 1994)
}

\author{
Michael Franz Reinhold Popović \\ Wiesenstrasse 22, 65817 Eppstein, Germany. E-mail: michael.popovic@t-online.de
}

The 80th birthday anniversary of Pavel Schmidt is an opportunity to recognize and celebrate his accomplishments in the fields of hygiene, environmental medicine, medical microbiology, and infectious epidemiology at the national and European level. He is remembered for his extraordinary commitment and contribution to the transformation process of health system in the Czech Republic (CR) after the "velvet revolution".

Pavel Schmidt was born in Prague. He started his medical education at Charles University in Prague in 1954. He obtained his $\mathrm{PhD}$ from the same University and in 1968 he obtained habilitation in hygiene and epidemiology. In addition, he worked for the Prague Institute for Hygiene and at the Faculty of Hygiene at the Institute for Doctoral Training. He was elected a member of the New York Academy of Science in 1970. Schmidt was granted research fellowship at the Alexander von Humboldt Foundation in Düsseldorf with Prof. Hans-Werner Schlipköter, M.D., between 1967-1973. Thanks to his commitment, Charles University in Prague established official bilateral relation with Heinrich Heine University in Düsseldorf. He organized an exchange programme for the interns of both universities. His name is also associated with the discovery of methemoglobinemia in infants related to nutrition. In 1962, he was honored by the Czech Medical Association of J. E. Purkyně, Czechoslovakia, for work in this field. Schmidt was responsible for multi-center studies about the effect of air pollution caused by leaded gasoline on damages in children. His actions were aimed at promotion and protection of the environment that children could enjoy. His thinking was influenced by his friend Prof. Josef Švejcar, the pioneer of the Czech paediatrics. Nevertheless, recognition of his achievements could not prevent him and his family from fleeing Czechoslovakia in 1976. He received political asylum in the Federal Republic of Germany and came first to Düsseldorf and then to Giessen, where he accepted the position of Professor at the Hygiene Institute of Justus Liebig University (JLU) in 1978. He coordinated all activities as the director until his death. Schmidt was involved in numerous activities at the Faculty for Hygiene and Environmental Medicine of JLU as well as in the State Chamber of Physicians of Hesse (SCPH). Renowned for his work in different committees of the German Medical Association (GMA), Schmidt assumed various voluntarily functions within the self-administration system of the State Chamber of Physicians in Germany. He published more than 150 scientific essays and other educational materials, books and articles on hygiene. Only due to the long term strategically well planned work of Schmidt, it was possible to build on the existing bilateral relationship between East and West after the fall of communism. Multi-center-studies on topics such as environmental damages in Bitterfeld, Ruhr and the North Bohemian coal mining area were extended through research in the Rhine-Main area and Freiburg etc. After 1990, the research results of the long term studies were reported and discussed by scientists from CR, the former German Democratic Republic and the Social and Environmental Affairs Commission of the Parliament of the State of Hesse. Schmidt's initiatives demonstrated his idea that medical practice shall never be limited by political or geographical boundaries.

After the "velvet revolution" in Czechoslovakia, he organised a variety of activities mainly in Prague. Schmidt established relationships with prominent representatives of the Czech Medical Association, the Ministry of Health, the National Council, the J. E. Purkyně Association, to name a few. As a part of the transformation process set by Schmidt, he organised a series of meetings and events, for example: Symposium of the Federation of Czech Physicians (1990); Symposium about the Medical Chambers and Health Insurances of the Czech Association of Physicians and the Training Institute for Physicians and Pharmacists (1991); Conference of the Ad Hoc Working Group of the Internal Grant Agency (IGA) of the Czech Ministry of Health called "Targets and Ways of Implementation” (1992). Schmidt put strong emphasis on the inclusion of the European experts outside of Germany.

In close coordination with the representatives of GMA and $\mathrm{SCPH}$, he contributed in an extraordinary fashion to the rebuilding of the Medical Chamber in CR originally founded in 1894. Schmidt also distinguished himself in the medical scientific research support. He inaugurated the "Internal Grant Agency" and was its board member until his death. He also explored different development opportunities for medical research to overcome various challenging tasks. In 1992, the international ad-hoc working group of IGA of the Czech Ministry of Health developed concepts for research grants in the area of health, social and economic politics and the management of the public health system. Schmidt also reflected international economic relations and supported the development of concept papers by international consultants contributing to the economic aid to CR. The focus especially on clinical interdisciplinary research and international collaboration on joint research projects was improving in a remarkable quick manner. Schmidt was a committed and highly professional physician, teacher, scientist and health politician who thought and worked crossing different sorts of borders. We have to thank to Pavel Schmidt for his continuous competent advice, his support in the medical selfadministration and training as well as capacity building. 